\title{
THE PROMISE OF THE INDEX IN CONTEMPORARY DOCUMENTARY PERFORMANCE
}

\section{Solveig Gade}

\section{ABSTRACT}

This essay investigates the troubled status of the concept of the index and its concomitant notion of evidence within the context of a global, visual culture. Specifically, the essay centres on the notion of the index in an era, where the use of digital images claiming to truthfully represent war and conflict has become an increasingly important part of warfare. Focusing on two documentary works by respectively performance artist Rabih Mroué and visual artist Abu Lawrence Hamdan (Forensic Architecture), the article shows that whilst both artists rely on material documents, which in each their way index back to conflictual events, the crucial point is not so much the status of the evidentiary material per se. Instead, enabled by fictitious strategies, the artists invite us to pay attention to the differing statuses and meanings assigned to documents depending on the particular knowledge systems and spaces of appearance within which they are perceived. In this way, the essay argues, the works of Mroué and Hamdan help us move beyond the discourses within documentary theory, which tend to conform to either a postmodernist relativist position or a realist epistemology.

\section{KEYWORDS}

Contemporary Documentary Art, War and Conflict, Document, Index, Evidence, Archive, Rabih Mroué, Lawrence Abu Hamdan, Forensic Architecture

For quite some time now, the notion of the index, understood as a sign providing us with solid proof of its referent, has been in trouble. Arguably, the promise of the indexical sign to provide a causal link to reality has always been a contested affair. But the emergence of a global digital visual culture and the spread of cheap and accessible DIY-technologies for producing, distributing and manipulating visual content, has certainly brought to the fore the issue of the credibility of images claiming to index back to reality. Even so, while by now we may have come to regard images as potentially subject to manipulation, within present contexts of war and conflict images are routinely, and to an unprecedented degree, being deployed as means to document and convey what "really took 
place”. Indeed, as pointed out by W. J. T. Mitchell, in the twenty-first century images have gained ever more importance in the battle over the representation of war and conflict and in the fight for conquering the perceptual fields and imaginaries of global spectators. ${ }^{1}$ This development begs questions concerning the status of the ostensible indexical image (is it real or manipulated?). More importantly, it invites us to think about how images are imbued with truth-value despite the fact that they have most probably been manipulated one way or the other. This, in turn, prompts us to attend to who gets to decide on the status of the image in question and, in turn, on which images that come, within a certain distribution of the sensible, to be recognized as legitimate accounts of reality.

Within recent years, a number of documentary artists working in the visual and the performing arts have confronted issues pertaining to the question of the index within contexts of mediated war and conflict. Suffice it here to point to works by artists as diverse as Walid Raad, Rabih Mroué, Laura Poitras, Milo Rau, Arkadi Zaides, Rimini Protokoll and Forensic Architecture. In this article, I wish to investigate the troubled, yet enduring pertinence of the concept of the index and its concomitant notion of evidence through a reading of works by two of these artists, namely Lebanese performance artist Rabih Mroué and British-Jordanian Lawrence Abu Hamdan (affiliated with Forensic Architecture). The works in question-the lecture performance The Pixelated Revolution (2012) and the video installation Earshot (2016)-centre on respectively the conflict in Syria and the situation on the West Bank. In my reading of the works, I will be focusing on the ways in which the two artists combine evidence-driven, forensic techniques and fictitious strategies, and, in turn, how notions of evidence take on different meanings depending on the knowledge systems within which they are embedded.

In my analysis, the concepts of document, index and archive will hold a central position. As for the two former, I would like to focus on the indicative, evidentiary function typically ascribed to them as well as their assumed ability to point truthfully back to reality. The concept of the archive, in turn, will be instrumental in discussing the ways in which the act of interpreting and ultimately controlling documents are and have always been deeply entangled with operations of power. The first part of the article will provide a definition of these three key concepts and the ways in which they have been negotiated in varying historical contexts. For this purpose, I will be drawing on the work of Charles Sanders Peirce's writings on the index as well as Philip Rosen's work on 
the document and Jacques Derrida's seminal observations on the archive. Furthermore, I will be situating the works of Mroué and Hamdan within the trajectory of documentary performance by providing a brief overview of their predecessors in twentieth century theatre. Here, I will be relying on the writings on documentary by Erwin Piscator, Peter Weiss, Janelle Reinelt, Carol Martin, and Bill Nichols. Finally, throughout the analysis of the two works, Hito Steyerl's concept of poor images as well as Eyal Weizman's notion of forensics and Thomas Keenan's conceptualization of evidence when used within a legal context will be instrumental in pursuing the alleged indexicality of images.

\section{DOCUMENT, INDEX, ARCHIVE}

Before venturing into the concepts of the document, the index and the archive, a few remarks on the documentary is in order. As famously noted by film scholar Bill Nichols "documentary is what we might call a fuzzy concept." 2 Accordingly, different definitions of the concept abound, and judging from the contemporary landscape of hybrid documentary forms referred to by names such as "mocu-mentary", "new documentary", "fictive documentary", or even "post-documentary" 3 , it has become even harder to maintain the well-known definition of documentary as a non-fictional form to be distinguished from fictional form. However, as suggested by documentary maker John Grierson's seminal 1932 definition of documentary as the "creative treatment of actuality," 4 the boundary between documentary and fiction was always somewhat blurry. In the same vein, Bill Nichols has warned against subscribing to a stable, catch-all definition of the genre. Instead he stresses the inherent hybridity of the genre and its call for a continuous development of dynamic concepts since its truth value is negotiated repeatedly based on new documentary forms. ${ }^{5}$

However, in order to get us started I will, taking my cue from theatre scholar Janelle Reinelt, suggest that a minimal presumption of documentary is that it contains or cites documents. ${ }^{6}$

But what, then, does a document mean? In Change Mummified, film scholar Philip Rosen provides a helpful genealogy of the document based on the 1933 and 1989 editions of the Oxford English Dictionary. Originating from the Latin documentum and the Old French document, the noun "document", Rosen explains, entered the English language by the mid-fifteenth century, where it came to imply two meanings; one related to teaching and/or learning and one denoting evidence or proof. By the eighteenth century, documents were primarily associated with written accounts such 
as manuscripts or title-deeds, but could also encompass artefacts, including tombstones, coins and pictures. However, according to Rosen, with the rise in the nineteenth century of new indexical technologies, such as the photograph and the phonograph, as well as the emergence of the documentary genre in twentieth century film, theatre, and visual art, the concept of the document increasingly came to be associated with its authenticating, proof-like quality rather than its educative aspect. "The authority of documenting," Rosen contends, "was first drawn from the power implicit in its denotations, that is warning, admonishing, or teaching; it then became an evidentiary element in an argument or rhetoric; and currently, within a semantic history that seems linked to film, this authority can exceed even its modes of inscription, as a claim that achieves the authority of the real itself." 7 In other words, when deployed in, say, a documentary film, documents function, by way of their indexical relation to reality, as authenticating elements, which work to reinforce the credibility of the documentary and the reality claims it brings to the fore.

This brings us to the notion of the index, and in turn, to Charles Sanders Peirce, one of the founding fathers of semiotics. As part of the comprehensive sign system conceived by Peirce, the so-called second trichotomy attends to three overall different ways in which the sign may refer to its object. Whereas the icon refers to its object through similarity, and the symbol through interpretive habit or norm of reference, the index is defined by its factual, causal relation to its object. Because of its real connection to the object, the index, say, in the shape of an old-fashioned hygrometer, gets directly affected by the object and may thus afford "evidence from which positive assurance as to truth of fact may be drawn." 8 To further explain and elaborate his point about the direct, physical relation between the sign and the object, Peirce turns to photography and argues that whilst one might assume that photographs are iconic, they are in fact indexical. "Photographs," he writes, "especially instantaneous photographs, are very instructive, because we know that they are in certain respects exactly like the objects they represent. But this resemblance is due to the photographs having been produced under such circumstances that they were physically forced to correspond point by point to nature. In that aspect, then, they belong to the second class of signs, those by physical connection." 9 Below, I will return to Peirce's view on the photograph as a physical trace of the reality it purports to represent. But for now, I wish to point to the indicative, evidentiary function shared by the document and the index. Accordingly, in twentieth century discourses on 
documentary the concepts of document and index have often been conceived of as two sides of the same coin.

Moving on to the figure of the documentary artist, his or her acts of selecting and editing documents, which ostensibly hold an indexical link to reality can be-and have been (Rosen 2001)compared to the operations of the historian. Like the historian, the documentarist holds, or perhaps rather usurps, the power to organize the past through "controlling documents, indexical traces of the real past." 10 The ways in which the act of interpreting documents is deeply entangled with the exercise of power has been thoroughly investigated by Jacques Derrida in his seminal Archive Fever. In the book, Derrida reminds us that the meaning of the noun archive is derived from the Greek arkheion, initially meaning the house of the archons, those who command. In this house, as a matter of fact this home, official documents were filed and guarded by the archons to whom the authority to access and interpret the archive was bestowed. The archons performed and affirmed their power to rule by giving voice to scriptural documents, but in order to take place, in order to speak and impose the law, the documents themselves were conversely dependent on the speech acts of the archons.

The politics of the archive could thus be said to play itself out in an ongoing negotiation between the document and those interpreting and speaking it, thereby ensuring future enactments of the law and the particular social order implied by the archive. The archive is thus, as Derrida points out, not relegated to the past, but is very much a token of the future: "the question of the archive (...) is not the question of a concept dealing with the past that might already be at our disposal or not at our disposal, an archivable concept of the archive. It is a question of the future, the question of the future itself, the question of a response, of a promise and of a responsibility for tomorrow." 11 The license to access and interpret documents, the license to conduct processes of archiving in the sense of deciding what should be archived and handed over to posterity in order to be re-enacted once again, is, in other words, a deeply political affair.

\section{THE DOCUMENT IN TWENTIETH AND TWENTY-FIRST CENTURY THEATRE}

In twenty century documentary theatre, that is a strand of theatre which to a great extent has self-identified as political, or perhaps rather as oppositional to the politics pursued by those in power, playwrights and directors have consistently sought to intervene in and challenge the archive. That is to say, they have attempted to counter prevailing ideologies and ways of archiving by confronting 
audiences with-and inviting them to reflect critically upon official documents ranging from photographs, to film and statistics to hearings and transcriptions of trials and tribunals. Indeed, the theatre of director Erwin Piscator, working in Berlin in the 1920s and again during the 1960s, as well as that of playwright Peter Weiss, who spearheaded the German documentary drama of the 1960s, is based on a firm belief in the evidential proof-of-truth character of the document. Confident that audiences would shed the "false consciousness" thrust upon them by capitalist ideologies when confronted with the facts spoken by the documents presented, they both put great faith in the supposedly indexical relation of the document to the social reality existing outside theatre.

Piscator even went as far as to characterise his approach as scientific: "conclusive proof can be based only on scientific analysis of the material. [...] It is only from the facts themselves that the constraints and the constant mechanisms of life emerge, giving a deeper meaning to our private fate." 12 Along the same lines, Weiss believed strongly in the facticity of the documents presented and in the political potential of presenting them within the realm of documentary theatre. However, more overtly than Piscator did he acknowledge the process of selecting and editing that went into the act of transferring documents into the framework of documentary theatre. "Documentary theatre refrains from all invention," he thus contended, "it takes authentic material and puts it on stage, unaltered in content, edited in form." 13

However, the faith held by figures such as Piscator and Weiss in the "proof of truth" character of the document has been shaken decisively at the turn of the twentieth century onwards by the emergence of a global visual culture marked by mediatisation and digitization. Specifically, the supplanting of wet bath chemical processing of photographic film and paper with computer-based, photoelectric techniques have undermined the notion suggested by Peirce of the photograph as a physical trace causally indexing back to reality. Indeed, within today's connective, digital media scape, images are being produced, distributed, re-contextualized, altered, and circulated again at such a dizzying speed and to such an extent that we have almost come to expect them to have been digitally manipulated. Alongside the insights gained from poststructuralist critiques of representation, the mentioned technological innovations, including the spread of cheap DIY technology for producing and distributing visual and auditive documents have thus put unprecedented pressure on the (always troubled) notions of indexicality and evidence associated with the document.14 
While one could expect that the development mentioned above would lead to the waning of the documentary, this is by no means the case. On the contrary, across the arts the documentary mode has enjoyed a distinct revival since the late 1990s. ${ }^{15}$ Within the realm of theatre and performance, the upsurge of the documentary has manifested itself in two different strands. ${ }^{16}$ Whereas the first strand (associated particularly with verbatim theatre and tribunal plays) represents an almost positivist realist faith in facts, the second (associated with for instance the "imaginary archive" of The Atlas Group/Walid Raad) is defined by a consistent intermingling of found and invented documents, facts and fiction, official histories, and subjective memories. Accordingly, while the former is driven by an often overtly pronounced desire to set the record straight, the latter seems more preoccupied with investigating the very nature and materiality of documentation, including the ways in which documentary narratives are constructed and seek to persuade the recipient.

In an attempt to avoid the trap of siding either with a positivist realist or a post-modern relativist take on the documentary, a range of documentary scholars have argued in favour of a pragmatic approach, which seeks to combine the two. In the words of theatre and performance scholar, Carol Martin: "Theatre of the real's strategies are often postmodern, especially in asserting that truth is contextual, multiple, and subject to manipulation (...) Most importantly, creators of theatre of the real assert that meaning is within reach even while using postmodern theatrical strategies." 17 Along the same lines, aforementioned Janelle Reinelt suggests that documentary reality emerges performatively as an effect of the relational interaction between the document, the mediating artist and the spectator. "This way of understanding the epistemology of documentary," Reinelt contends, "credits what is objectively there as well as what is creatively produced and ultimately received." 18 Conceived this way, the document may be understood as something which is incomplete in itself, but which may nevertheless provide an indexical link to reality, corroborating "that something happened, that events took place." 19

At first sight, the realist approach suggested above comes across as sensible, as it seemingly allows us to combine a poststructuralist approach with a pragmatic take on reality. At a closer look, however, it raises a number of questions. For how can we decide on something as being "objectively there"? For whom does it appear to be "objectively there”, and when? And finally, who gets to decide when something is "objectively there", and when it is not? 
In the ensuing, I will seek to think through the implications of these questions through a reading of first, The Pixelated Revolution by Rabih Mroué, and second, Earshot by Lawrence Abu Hamdan. As I will attempt to show, these works invite us to move beyond discussions focusing on the ontological status (and the validity of the truth claims) of documents, and to focus instead on the underlying conditions and non-transparent power structures, which could be said to shape our epistemological approach to reality.

\section{THE NEW WEAPON OF THE TWENTY-FIRST CENTURY}

The actor, director and visual artist Rabih Mroué belongs to a generation of Lebanese documentary artists, who during the $1990 \mathrm{~s}$ and 00s set out to address the still unresolved Lebanese Civil War, which took place between 1975 and 1990. Thus, internationally acclaimed artists such as Walid Raad, Akram Zaatari, Lina Saneh, Jalal Toufic, Tony Chakar, Lamia Joreige, and Rabih Mroué himself, have challenged not only the "state sponsored amnesia" 20 imposed from above in order to avoid the eruption of a new grand scale conflict in Lebanon. They have also distanced themselves from the biased accounts of the war and the one-sided truths unofficially propagated by competing sectarian communities. ${ }^{21}$ Specifically, the artists in question have insisted on engaging with the past and the war through a panoply of documents spanning from found objects to photographs obtained from The Arab Image Foundation to subjective memories and fictitious accounts. Through in this way unhinging conventional binaries, such as fact versus fiction, or official versus private, these documentary strategies have provided a means for engaging with the many "truths" and possible histories surrounding the Lebanese Civil War. ${ }^{22}$

Throughout his work, Mroué has been particularly preoccupied with the politics of images, more specifically, the use of images as a kind of supplementary warfare. In The Pixelated Revolution, he continues to pursue this problem, but instead of the Lebanese Civil War his site of inquiry has shifted to the ongoing conflict in Syria and the new weapon of the twenty-first century: the cell phone camera. In the piece, which dates back to the early days of the conflict in Syria, ${ }^{23}$ Mroué explains that in his determination to gain knowledge about a strife, whose coverage was initially almost monopolised by the Assad-loyal Syrian state media, as notoriously few international news agencies had access to Syria, he decided to turn to another source. He decided to turn to the video documentations of protests and violent events recorded and uploaded to the internet by Syrian protesters via social media such as Facebook and YouTube. ${ }^{24}$ 
In keeping with the terminology of this article, I suggest to conceive of the Internet as a gigantic digital archive and the videos deployed by Mroué as visual documents retrieved from the archive. As far as the documentary artist selecting, editing and combining the documents is concerned, Mroué clearly stages himself as a trustworthy and sincere academic within the framework of the lecture performance. Thus, seated in a black box at a table with his laptop and a script in front of a screen, upon which he continuously projects footage, Mroué unfolds his findings and line of reasoning in a calm and overtly academic manner. However, at a closer glance it soon becomes clear that during the lecture he subtly assumes at least three different positions, namely those of an aesthetically informed academic, a crime scene investigator, and a philosopher. Therefore, even though Mroué initially claims to be looking for "facts" and "evidence" 25 about the conflict, the spectator gradually realizes that more than anything, Mroué is exploring how diverse forms of knowledge formations shape our view on and approach to phenomena, sometimes referred to as "facts" and "evidence".

As for the first position, that of the aesthetically informed academic, it is enacted through the undertaking of an aesthetic analysis of the images of the protesters. ${ }^{26}$ Plotted against the Syrian news channels' use of the three-legged tripod, which is taken to discretely serve "as a reminder that the solidity of the state is unquestionable and its image uncontaminated and unshakable," 27 Mroué takes note of the pixelated, blurry and unstable formal aesthetics of the protester images. ${ }^{28}$ The formal analytical approach leads Mroué to further compare the recommendations shared amongst protesters on how to record protests without being or having others identified, with the Danish Dogme 95 film manifesto. Claiming that the imperative recommendations exchanged by Syrian protesters on social media-"Shoot from the back and do not show faces (...) Rely on a hand-held camera only"resembles the tone of a cinematographic manifesto, Mroué creates "A list of guidance on how to film a demonstration." 29

The provocative juxtaposition of, on the one hand, privileged Scandinavian fiction film directors, who wanted to distance themselves from the illusion of mainstream Hollywood film, and, on the other, Syrian protesters seeking to document their struggle to the international community, could be read as a selfconscious, ironic comment on the pitfalls of a purely formalistic and de-contextualizing approach to images of conflict. At the same time, however, one could argue that the juxtaposition makes visible how fiction and documentary do rely on a set of 


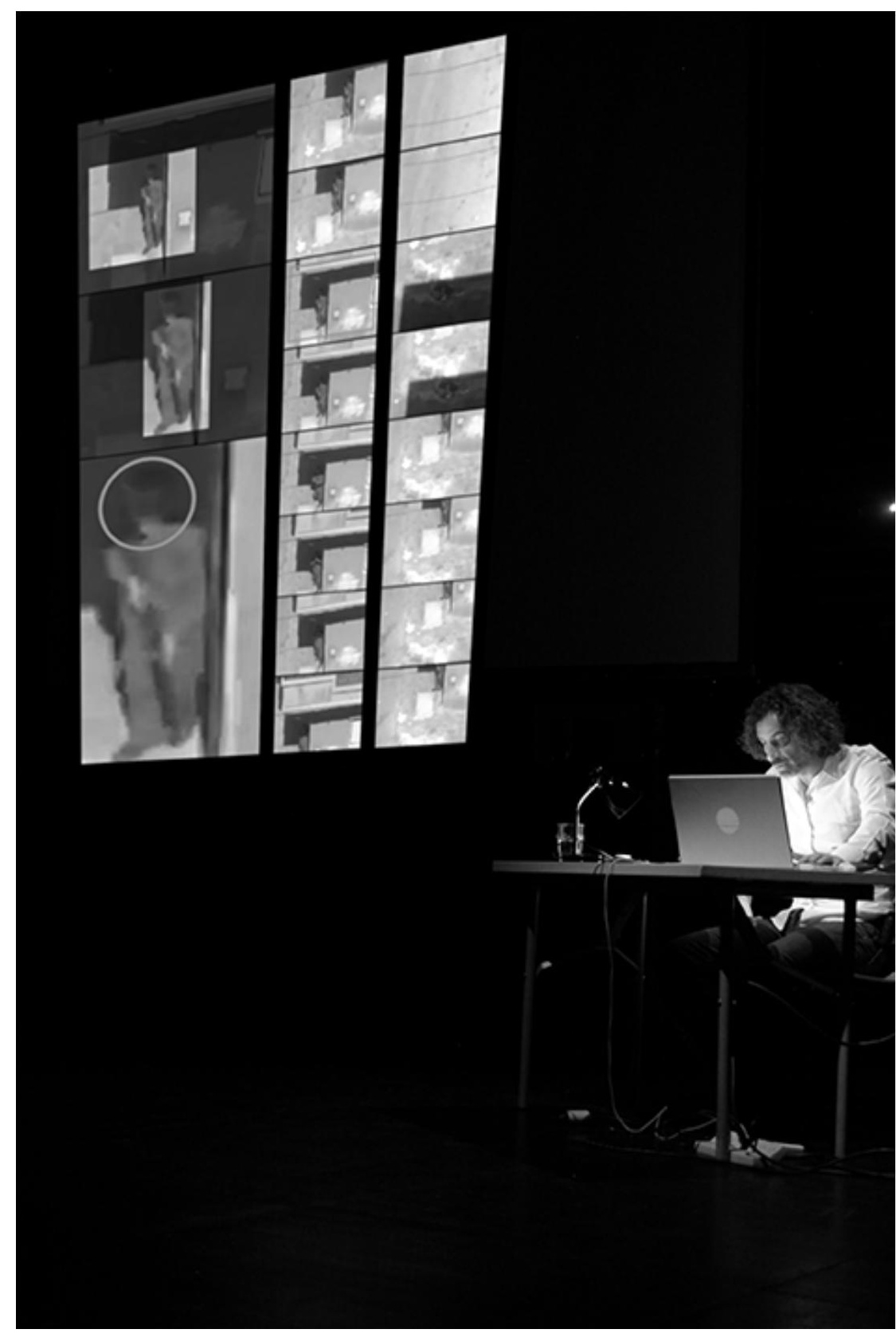

Rabih Mroué, The Pixelated Revolution, lecture performance.

Photo by Ernesto Donegana. 
shared formal techniques, such as the use of handheld camera, for creating the authenticity effect ${ }^{30}$ desired by both the Dogme film directors and the Syrian protesters. Likewise, it could be argued that the juxtaposition brings to the fore the fact that the recipient's perception of the recorded reality is inevitably informed by the frame or perspective chosen by the camera man. In effect, the juxtaposition could be said to address the increasing blurring of boundaries between documentation and participation, which currently takes place in contemporary conflict coverage relying on eyewitness images. ${ }^{31}$ Differently put, the juxtaposition discretely points to how the notion of the non-biased witness has become increasingly complicated and hard to maintain as a result of the ubiquitous use of images as documents, as evidence, and ultimately, also as weapons, within the context of contemporary conflict and warfare.

In the performance, the pixelated, often hardly discernible images snapped on the fly by protesters thus represent the kind of eyewitness images in which the cameraman is pushed to the fore as an active engineer of reality. To capture better the quality of the blurry images of the protesters we could, with media artist and theorist Hito Steyerl, define them as poor images. That is, bad quality and low-resolution digital images circulating on the Internet, constantly exposed to manipulation and re-contextualisation. Indeed, rather than revealing to us their actual content, such images may tell us something important about the conditions under which they were taken and also about the status assigned to them. Steyerl phrases it this way: "[poor images'] situation reveals much more than the content or appearance of the images themselves: it also reveals the conditions of their marginalization, the constellation of social forces leading to their online circulation as poor images.” 32

The failure of poor images to provide us with clear and unambiguous evidence is explored in Mroué's enactment of a crime scene investigator, obsessively conducting a forensic analysis of a video referred to as Double Shooting. The content of the video is viewed through the lens of a mobile phone camera belonging to a Syrian protester, who captures and "shoots" a sniper with his camera. In return, the sniper captures the protester through the sight of his rifle and shoots back at him. The camera falls to the ground, and the image goes black. In his effort to identify the perpetrator, Mroué as crime scene investigator, turns to Optography and the belief held by some scientists in the late nineteenth century that the retina of the eye is capable of recording the last series of images seen before death. Within certain fields of crime investigation, it 
was consequently believed that through gaining access to the last images seen by a victim of murder, one would be able to identify the perpetrator. Suggesting that the cell phone camera could be seen as an extension of the camera man's eyes and thus-through its recording of the last images seen by the camera man-help establish the identity of the sniper, Mroué engages in an obsessive forensic analysis of the video. He plays it in slow motion, he breaks it into different frames, he zooms in on the pictures.

His hope is that this may help him establish the identity of the killer, who can then, at some future point in history, be taken to court. As Mroué has it: "It was my attempt to sketch a picture of the murderers and divulge their personal identities; a desire to know the surname and the family name of the murderers, for they could walk among us tomorrow." ${ }^{33}$ But for all Mroué's efforts, the image remains blurry, refusing to provide him with the certainty that could be used to identify the sniper and ultimately hold him accountable for his deeds. "There is nothing to see," Mroué thus concludes, "but a face with no eyes and no features. But why are we not able to see the face? Is it because murderers hide behind a collective identity, a diluted identity, one that is referred to as the "regime'?"34

Finally, towards the end of the performance, Mroué assumes the shape of a somewhat speculative philosopher, who ponders whether the cameraman did actually die, when his cell phone fell to the ground. Claiming that we never actually witness the moment of death of the cameraman, Mroué posits that it is never possible to record the moment of death, because this crucial moment "is stretched in two directions at once-life and death-thus causing borders and separations to dissolve." 35 This observation leads Mroué to the somewhat surprising suggestion that since the recording of the cameraman is still "alive" and available for us to watch, so too the cameraman must be alive. While one might rightly question the legitimacy of this line of reasoning, I am interested in the implications of maintaining, of keeping open the ambiguous space between life and death mentioned by Mroué. With respect to the many Syrian activists who died whilst shooting the atrocities of the Assad regime, at least one important implication seems to be that helping to ensure the continued circulation of the videos would be a way of rendering those who died undead.

To conclude, then, in spite of their indexical representations of violent events and cold-blooded murderers, the poor technical quality of the videos means that it is rather unlikely that they could ever be used as evidence against individual persons within a legal setting. Yet, the pixelated images taken and distributed by the 


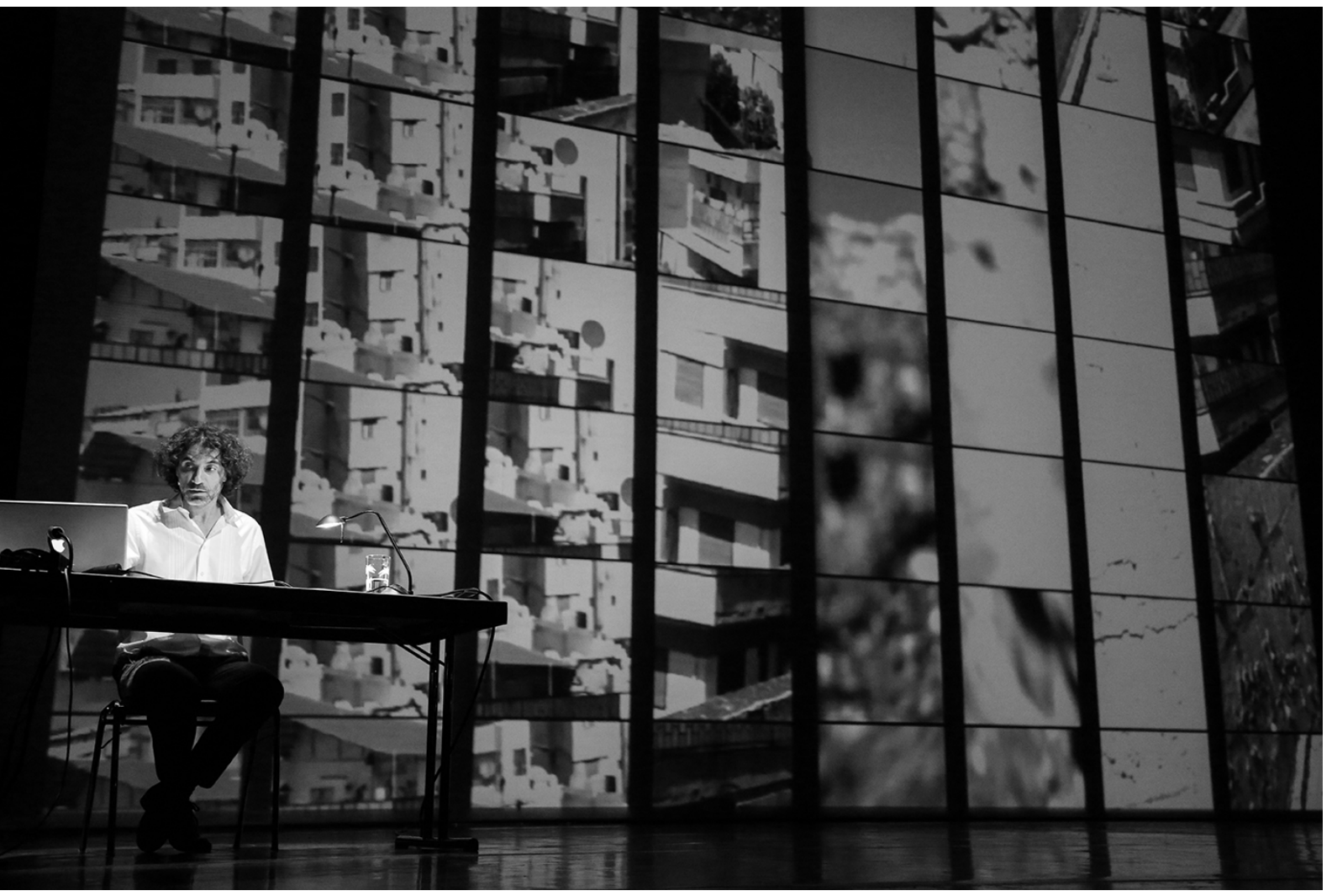

Rabih Mroué, The Pixelated Revolution, lecture performance.

Photo by Pascheit Spanned, () Gallery Sfeir-Semler. 
protesters-indeed, the precarious archive that they seek to build to counter the tripod-enabled visual archive of the Syrian state channels-do work as a testament to the conditions and the reality endured by Syrian citizens and protesters. As far as Mroué's lecture performance is concerned, through its transference of the videos found on YouTube to the discursive space of the art institution, it could be said to help maintain the continued circulation of the videos and, ultimately, the memory of the anonymous mass of Syrian citizen, who recorded the videos.

\section{THE POLITICS OF LISTENING}

The second case study of this article will focus on the video installation Earshot by British-Jordanian artist and audio investigator Lawrence Abu Hamdan. In recent years, Hamdan has gained broad recognition for his consistent and unorthodox artistic investigations of the intersection of sound and politics. Cases in point are The Freedom of Speech (2012) and Sayndaya (2016). In the former Hamdan investigates the use of de-humanizing so-called forensic listening techniques deployed by British immigration officers to the vetting of asylum seekers. In the latter he relies on the use of earwitnesses, former inmates, to help reconstruct the architecture, and in turn, the atrocities taking place within the Syrian regime prison Sayndaya. Hamdan is affiliated with (and completed his PhD within the framework of) Forensic Architecture, based at Goldsmiths University of London. Before plunging into the analysis of Earshot, I will briefly explain the notion of forensics.

Headed by architect and professor Eyal Weizman, Forensic Architecture is both an emergent academic field and a research agency, which undertakes architectural and media research on behalf of international prosecutors and human rights institutions. In the introduction to the 2014 book Forensis, Weizman positions the practices of Forensic Architecture in relation to the so-called forensic turn, which has taken place across international law, human environmental science and popular culture over the past three decades. Marked by an increasing scepticism about the sole reliance on human testimonies (since the witness' memory may be faulty, traumatized or subject to manipulation), the forensic turn implies a distinct interest in and a heightened sensibility towards material objects and findings. ${ }^{36}$ Weizman, however, warns against simply replacing the faith in, if not the sanctity of, the human witness, with material remains. Instead of arguing for a clear-cut distinction between on the one hand subjective testimony and, on the other, hard material evidence, he contends that the two are both 
defined by ambiguity and uncertainty, in the same way as they are both subject to probability and margins of error.

In expansion, Weizman distinguishes between police forensics, which according to him should be understood as a disciplinary tool meant to affirm the power of the state, and a "new forensics" or Forensis aimed at challenging received forensic practices. Whereas the former could be said to rely on a notion of the ability of facts and evidence to provide a scientifically approved account of truth, as it were, the ladder pays just as much attention to the in-transparent, inherently political processes which determine when something is assigned the status as evidence, and when it is not, as it does to the piece of evidence itself. "Forensis," Weizman explains, "should thus be understood as something akin to a 'critical forensic practice' that introduces both the production of evidence and the querying of the practices of evidence making." 37 Just as importantly, a "critical forensic practice" would include a presentation of such queries and findings across a number of public fora.

Turning to Hamdan's Earshot, the work could be said to build on exactly the kind of critical forensic analysis referred to above. In all brevity the work takes its point of departure in the shooting and killing of two young civilian Palestinian protesters, Nadeem Nawara and Mohammed Mahmoud Odeh Abu Daher, on the West Bank in 2014. The Israeli military was present on the scene, but pleaded not guilty and claimed that they had only fired rubber bullets. Subsequently, the human rights organisation Defence for Children International contacted Forensic Architecture, and Hamdan agreed to work with the organisation to investigate the incident. Through a detailed forensic audio analysis of the recorded gunshots, in which Hamdan used special techniques designed to visualise the sound frequencies, he could establish that the Israeli soldiers had fired live rounds, and moreover that they had tried to disguise this by firing the shots through a rubber bullet adapter. The findings of the report published by Hamdan and the organisation were broadcast by international media, and also discussed in the US Congress. Yet the case never came before a civil court.

In the video installation Earshot from 2016, Hamdan integrates his research into a fictitious trial. Featuring colourful panels hanging at eye level, suspended from parallel beams in the ceiling, the space of the installation loosely resembles the architecture of a firing range. The allusion becomes even more obvious when the spectator realises that the panels are in fact spectrograms: visualisations of the sounds of the various projectiles used as evidence in the case. The 22-minute video Rubber Coated Steel 
constitutes the main part of the installation, and at Moderna Museet in Stockholm, where I experienced Earshot, it was projected onto a screen positioned centrally in the installation. ${ }^{38}$ Visitors were invited to sit down on two benches in front of the screen.

Playfully mimicking and twisting the practices of documentary playwright Peter Weiss and the earlier mentioned documentary tribunal plays of today, the video builds on the transcript of a tribunal that could have been conducted against one of the Israeli soldiers who shot and killed the young, unarmed Palestinian protesters. However, in accord with the shift from human testimonies to material investigation sketched out above, none of the eyewitnesses present at the event, where the two Palestinian protesters were killed pay testimony. Instead, the piece centres on the prosecution's questioning of an expert witness. More specifically, it centres on the findings of an audio forensic expert, who based on his analysis of the recording of the shootings obtained from a Palestinian News crew argues that the Israeli soldiers did indeed fire live rounds. However, neither the audio document presented by him, nor his analysis have any effect whatsoever on the judge or in the courtroom. The scenography of the video reveals a shooting range, doubling that of the installation. As the exchange between the prosecution, the expert witness, the defence, and the lawyer unfolds, spectrograms, photos and graphs (having replaced the targets that are usually found in a firing range) move back and forth in the shooting range. Except for the screeching sound of the range's automated machinery, there is no sound in the video. Thus, the transcript of the tribunal is presented in a series of subtitles on the screen and the sound of the fatal shots is translated into the visual spectrograms.

Taking his point of departure in the audio documents he has been entrusted with, in Earshot Hamdan could be said to insist, albeit with a twist, on the contested physical relation between the indexical sign and its object. However, it is by virtue of the very same digital technologies that are often claimed to have put an end to the indexical relation between the photograph and its referent that Hamdan is able to re-establish an indexical link (embodied by the material spectrograms hanging in the exhibition) between the sound recording and the crime scene. As such, his reliance on the indexical sign certainly provides him with "evidence from which positive assurance as to truth of fact may be drawn," as Peirce has it.

However, I would contend that the evidence presented is not the main focus of the work. Instead, what plays the central role is the way in which the seemingly indisputable piece of evidence is treated 


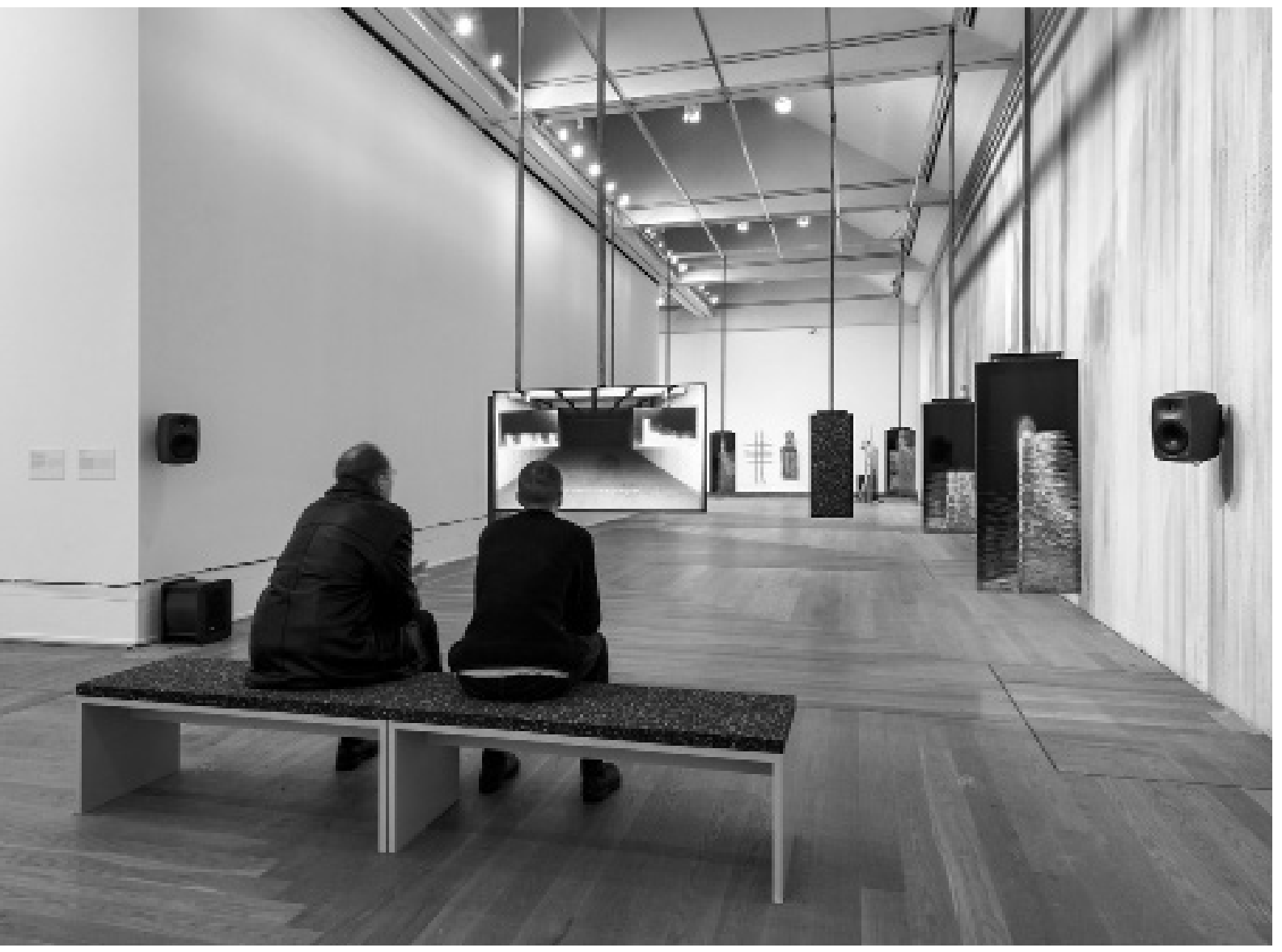

Lawrence Abu Hamdan, Earshot. Moderna Museet, 2017.

Photo by Åsa Lundén 


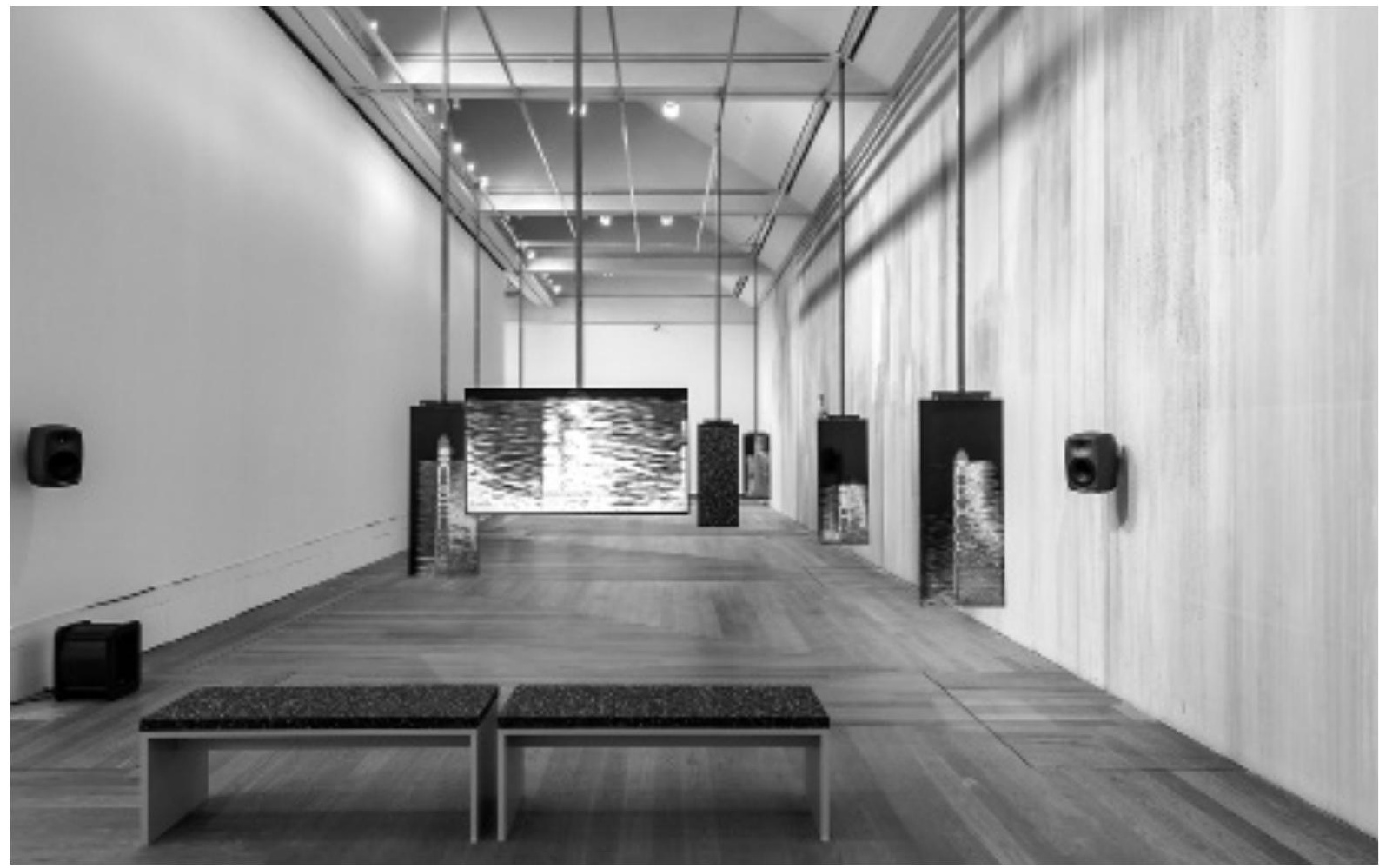

Lawrence Abu Hamdan, Earshot. Moderna Museet, 2017.

Photo by Åsa Lundén 
by the Israeli legal system. The way in which it is systematically thrown into doubt, ignored, and ultimately denied. Director of the Human Rights Programme at Bard College Thomas Keenan's understanding of the concept of evidence when used within a legal context may shed further light on this issue. In Forensis Keenan posits that evidence does not just designate what is objectively there but is very much a matter of appearance, of what manifests itself within the realm of visibility. "Evidence is what enters or is admitted into a specific domain of visibility or audibility." 39 Within the context of a legal setting this basically means that evidence should most of all be understood as that which is used to persuade the judge and the jury: "[i]t is that upon which a decision can be rendered about what the facts in a case are." 40

Accordingly, instead of listening to the sound recordings and acknowledging the sound difference between rubber bullets and live ammunition, in Earshot the judge admits he has "somewhat of a tin ear" 41 for such nuances, whereupon he willingly lets the defence lawyer derail the examination of the expert witness. Undergirded by the monotonous refrain of the defence lawyer crying out "objection" every time he is presented with a piece of evidence and the judge accommodating his plea with a "sustained", Hamdan draws our attention to the larger structures of a legal system in which some information is assigned the status of evidence to be taken into account, whereas other information is ruled out.

This point is emphasised in the last scene of the video, in which the prosecutor calls on the Palestinian youths present in the audience to step forward. In their capacity as both eye witnesses to the murderous event and real experts when it comes to instinctively telling the sound of live ammunition from rubber-coated steel, the prosecution calls on them to testify to the killing sounds of the recording. Their response is "inaudible", as it says in the transcript. An interpreter is summoned, but the response of the youths remains "inaudible”. "Do you hear me?", the prosecutor, and later the judge, ask. "It doesn't seem there is anything medically wrong with their hearing," 42 the witness remarks. But the youths remain at the back of the room, inaudible.

As pointed out by Anika Marschall, unlike a great deal of verbatim theatre Hamdan's works are not so much about giving "voice to the voiceless" as they are about producing a "new sensibility for the act of listening." 43 This also applies to Earshot, which through amplifying the silence of the victims could be said to draw attention to the politics of listening, but also, I would contend, to the politics of choosing to remain silent. 44 The politics of refusing to respond 
verbally to someone who does not listen anyway. However, it is not only the Israeli legal system's lack of listening skills that is on trial, as it were. The spectator's listening skills are also questioned. Seated on the bench in the exhibition space, which had been transformed into a combination of firing range and courtroom during the video, I as a spectator gradually became aware of my own role as a witness, perhaps even a juror, and not least an accomplice. To me the sounds of the Palestinian witnesses were also inaudible. Nevertheless, by pointing this out, Hamdan's work may teach us to be attentive to our own acts of (not) listening and to how we as subjects are inevitably embedded in a larger politics of listening.

\section{UNSETTLING KNOWLEDGE SYSTEMS}

In their works Mroué and Hamdan both assign to themselves the power which according to Derrida originally belonged to the figure of the archon, that is, the power to access, investigate, and bring to the public's attention the content of documents. The documents used by the two artists belong to very different contexts. Whereas back in 2011, the Syrian protest videos were available for everyone to access on the gigantic digital archive known as the Internet, the audio footage of the shots fired on the West Bank only became available to Hamdan because of his affiliation with Forensic Architecture. What is common to the approach to the documents of the two artists, however, is that neither of them fundamentally doubts their legitimacy. In fact, they both appear to assume that the documents do indeed provide a kind of indexical link to reality and may therefore serve as proof "that something happened, that events took place,” as Reinelt has it. However, as I have tried to show above, it is not so much the truthfulness, legitimacy, or ontological status of the document, which typically comes with discourses on the index that preoccupies Mroué and Hamdan. On the contrary: in his work, Mroué performs a veritable mocking exercise of the idea that through the use of forensic analysis resembling those used in crime scene movies, we should be able to establish what happened, identify the perpetrator and ultimately secure justice. In the same vein, in Earshot it is not so much the proof (embodied by the audio recording) that live ammunition was fired at unarmed Palestinian teenagers that plays the main role. Instead, the focus is placed on the possible journey and treatment of this piece of evidence through the Israeli legal system. For both artists, then, it seems that the lure of the document consists in its ability to provide a point of departure for critically investigating prevailing epistemological frameworks, which could be said to determine the appearance of bodies, things, 
and lived events and, by implication, whether or not documents indexing back to them are assigned the status of evidence.

Returning to the question raised at the outset of this articlehow to conceive of the status of the document in contemporary documentary performance-I would thus like to challenge the pragmatic positivist approach to the document suggested by Janelle Reinelt. As the analysis of the works by Mroué and Hamdan have shown, the question of the status of the document is not a straight forward matter of observing what is objectively there On the contrary, what is agreed to "be there", and in turn acknowledged as a legitimate piece of evidence, is, as Keenan has it, very much a question of what is admitted into a specific domain of visibility or audibility. In the phrasing of French philosopher Jacques Rancière we could refer to this as a matter of the distribution of the sensible, that is the overall law which within a given community implicitly organises and rules modes of perception. As per Rancière, then, the distribution of the sensible sets the division between what is visible and invisible, what is audible and inaudible, what can be said, thought, and done and what cannot. As such, the distribution of the sensible constitutes a "primary aesthetics" (aisthesis) or an aesthetic order in the broad sense of the term, ${ }^{45}$ which ultimately decides what can be apprehended by the senses and, in effect, what is common to a given community.

In their works, Mroué and Hamdan could both be said to intervene in the distributions of the sensible, the archive, if you will, which ultimately determine what we can see, speak and hear. Mroué does so by contesting the stable, tripod-enabled official images represented by the Assad regime through the use of the poor images of the protesters, while Hamdan challenges the convenient deafness of the Israeli legal system with his visualisations of the gun shots that killed two unarmed Palestinian teenagers. A crucial aspect of the two artists' use of documents indexing back to reality, however, is their combining of these documents with fictitious strategies. For Mroué, the enactment of a number of roles (the academic, the detective, the philosopher) allows him to discreetly map out a number of different conventions for producing knowledge in order to ultimately question the meaning and the status ascribed to documents by different regimes of knowledge systems. Along the same lines, Hamdan inserts the actual research conducted by him into a simulated trial without ever giving away to the spectator that the trial represented in the video is indeed fictitious.

Such ways of merging fact and fiction do, of course, create a fundamental uncertainty with respect to the status of the material 
at hand: Can the documents be trusted at all? However, this strategy of assembling might also be seen as a way of unsettling both the forms of knowledge and the underlying power structures to which we more or less unwittingly conform when engaging with mediated accounts of war and conflict. Ultimately, then, the works draw our attention to the various systems of knowledge and meaning making through which evidence is produced, processed, and validated. Concurrently, however, the works also create temporary spaces for us to go beyond, challenge, and perhaps even re-imagine these systems and the prevailing distributions of the sensible. Therein, I contend, lies the potential and the promise of the notion of the index in contemporary artistic documentary. 
1 W.J.T Mitchell, Cloning Terror: The War of Images. 9/11 to the Present (Chicago and London: The University of Chicago Press, 2011), 2-3.

2 Bill Nichols, Introduction to Documentary (Bloomington: Indiana University Press, 2001), 21.

3 See Stella Bruzzi, New Documentary (London \& New York: Routledge, 2000), T.J. Demos, The Migrant Image: The Art and Politics of Documentary during Global Crisis (Durham \& London: Duke University Press, 2013), and Ine Gevers, "Images that demand Consumation: Postdocumentary Photography, Art and Ethics" in Documentary Now!, ed. Frits Giertsberg, Maartje van den Heuvel, Hans Scholten (Rotterdam: NAI publishers, 2005): 138-177.

4 Grierson, "The Documentary Producer", Cinema Quarterly, 2:1 (1933), 8.

5 Nichols, Introduction to Documentary, 21.

6 See Janelle Reinelt, "The Promise of Documentary" in Get Real: Documentary Theatre Past and Present, ed. Alison Forsyth and Chris Megson (Basingstoke: Palgrave Macmillan, 2009), 7.

7 Philip Rosen, Change Mummified: Cinema, Historicity, Theory (Minneapolis: University of Minnesota Press, 2001), 236.

8 Charles Sanders Peirce, Collected Papers of Charles Sanders Peirce, ed. Charles Hartshorne and Paul Weiss, Vol. IV, Book II (Cambridge: Harvard University Press, 1933), 447.

9 Ibid, Vol. II, Book II, 1932, 281.

10 Rosen, Change Mummified: Cinema, Historicity, Theory, 234.

11 Jacques Derrida, Archive Fever (Chicago and London: The University of Chicago Press, 1998), 36.

12 Erwin Piscator, "The Documentary Play" in Voicings: Ten Plays from the Documentary Theatre, ed. Attilio Favorini (Hopewell, New Jersey: The Eccho Pres, 1995), 8.

13 Peter Weiss, "The Material and the Models: Notes Towards a Definition of Documentary Theatre", Theatre Quarterly 1 (1971), 41.

14 For more on the troubled notion of the indexicality of the photograph in contexts of war and conflict, see for instance Susan Sontag's Regarding the Pain of Others (New York: Picador/Farrar, Straus and Giroux, 2003) and Jan Miezkowski, Watching War (Stanford: Stanford University Press, 2012).

15 See for instance Carol Martin, ed., Dramaturgy of the Real on the World Stage (Basingstoke: Palgrave Macmillan, 2010) and Theatre of the Real (Basingstoke: Palgrave Macmillan, 2013), Forsyth and Megson (2009), Erika Balsom and Hila Peleg, ed., Documentary Across Disciplines (Cambridge, Massachusetts: The MIT Press, 2016), Demos (2013) and Julian Stallabrass, Documentary (London: Whitechapell Gallery, 2013)

16 Daniel Schulze, Authenticity in Contemporary Theatre and Performance: Make it Real (London: Bloomsbury Methuen Drama, 2016), 234.

17 Martin, Dramaturgy of the Real on the World Stage, 3.

18 Reinelt, "The Promise of Documentary", 11. My emphasis.

19 Ibid, 10.
20 Fawwaz Traboulsi, "Foreword: Posters as Weapons" in Zeina Massri, Off the Wall: Political Posters of the Lebanese Civil War (London \& New York: I.B. Tauris, 2009), xvii-xviii.

21 See Sune Haugbølle, War and Memory in Lebanon (Cambridge: Cambridge University Press, 2010), 161-194.

22 See Solveig Gade, "Learning to live with Ghosts in the Aftermath of War", Journal of War \& Culture Studies, 8:4 (2015), 332-333.

23 I experienced the performance, which has been touring widely, at The Danish School of Stage Art in June 2013.

24 Mroué's somewhat one-sided reliance on and obvious sympathy for the protesters should be seen in the light that the performance was created in 2012 , when the situation in Syria was not near as complex as today with respect to the possible belonging and allegiance of Syrian insurgents to violent factions such as ISIL.

25 Rabih Mroué, "The Pixelated Revolution", TDR: The Drama Review 56, 3 (2012), 25.

26 See also Carol Martin "Pieces: The Pixelated Revolution", TDR: The Drama Review 56, 3 (2012), 19-20.

27 Mroué, "The Pixelated Revolution", 32.

28 As the conflict in Syria has dragged on, citizen media activists have become increasingly skilled, and highresolution images have supplemented blurry cell phone recordings (for more on this, see Mette Mortensen and Nina Grønlykke Mollerup, "Proximity and Distance in the Mediation of Suffering: Local Photographers in WarTorn Aleppo and the Internatonal Media-Circuit" in the forthcoming issue of Journalism.

29 Mroué, “The Pixelated Revolution", 26-27.

30 See Ulrike Garde and Meg Mumford, Theatre of Real People: Diverse Encounters at Berlin's Hebbel am Ufer and Beyond (London: Bloomsbury Methuen Drama, 2016), 69.

31 See Mette Mortensen, Journalism and Eyewitness Images: Digital Media, Participation, and Conflict (New York and London: Routledge, 2015), 3-4.

32 Hito Steyerl, "In Defense of the Poor Image" in Hito Steyerl, The Wretched of the Screen (Berlin: Sternberg Press, 2012), 38.

33 Mroué, "The Pixelated Revolution", 30.

34 Ibid.

35 Ibid., 35.

36 In Mengele's Skull: The Advent of a Forensic Aesthetics (2012), Weizman has, together with literary scholar Thomas Keenan sought to illustrate the implications of the shift from human testimony to material remains by contrasting the 1961 Jerusalem trial of Adolf Eichmann with the exhumation in $\mathbf{1 9 8 5}$ of the body of SS officer Josef Mengele. Whereas the former gave birth to what has been called "the era of the witness", the process by which Mengele's remains were identified unleased, according to Weizman and Keenan, a new forensic sensibility to objects and bodily remains. Consequently, bones, for instance some of those which were found in the exhumations of mass graves in Bosnia and Herzegovina have started to appear in international courts and war crime trials as a kind of "mute witnesses". 
37 Eyal Weizman, “Introduction: Forensis" in Forensis: The Architecture of Public Truth, ed. Forensic Architecture (Berlin: Sternberg, 2014), 12.

38 The work was commissioned by and initially shown at the German art space Portikus in 2016.

39 Thomas Keenan, "Getting the dead to tell me what happened", Forensis (2014), 43.

40 Ibid., 45.

41 Lawrence Abu Hamdan, "Rubber Coated Steel", Hearings: The Online Journal of the Contour Biennale, 30 June, 2016 http://hearings.contour8.be/2016/06/30/ assembly-hearings, accessed 15 January 2018.

42 Ibid.

43 Anika Marschall, "To Speak the Truth, The Whole Truth and Nothing But the Truth: About Political Performances of Listening", Platform, 11 (Autumn), (2017), 67.

44 In a written contribution to Forensis Hamdan fascinatingly argues that with the spread of techniques for forensic listening, the issue is no longer whether one is being deprived of the right to speak, but instead whether one is denied the right to remain silent. Referring to the consistent use of forensic listening by immigration officers, he posits: "Without the right to silence, the asylum seeker is forced to speak to the law; they must make themselves audible to the system and yet remain without control over the conditions of how they are being heard. [...] Now it seems that the battle for free speech is no longer about fighting to speak freely, but fighting the control over the very conditions under which one is being heard." (Hamdan, "Aural Contracts" in Forensis: The Architecture of Public Truth, ed. Forensic Architecture, 75.

45 Jacques Rancière, The Politics of Aesthetics (London and New York: Continuum, 2005), 13. 